\title{
An eighteenth century travelling theodolite
}

\section{Um teodolito viajante do século XVIII}

\section{Isabel Malaquias}

Professora, Departamento de Física e Centro de Investigação "Didáctica e Tecnologia na Formação de Formadores"/

$$
\begin{gathered}
\text { Universidade de Aveiro. } \\
\text { Campus de Santiago } \\
\text { 3810-193 - Aveiro - Portugal } \\
\text { imalaquias@ua.pt }
\end{gathered}
$$

\footnotetext{
Recebido para publicação em abril de 2014.
} Aprovado para publicação em novembro de 2014.

http://dx.doi.org/10.1590/S0104-59702016000300004
MALAQUIAS, Isabel. An eighteenth century travelling theodolite. História, Ciências, Saúde - Manguinhos, Rio de Janeiro, v.23, n.3, jul.-set. 2016, p.669681.

\section{Abstract}

An old topographic compass displayed in a showroom of the Museu de Astronomia e Ciências Afins (MAST), in Rio de Janeiro, Brazil, took our curiosity namely because of its resemblance to a theodolite, described by J.H. de Magellan. Not many things were known about its previous history. From the different documents studied, and the characteristics of this singular theodolite, it must have belonged to the collections of instruments acquired for the Brazilian border demarcations undertaken after the Santo Ildefonso Treaty, agreed to by the Portuguese and Spanish courts in 1777. Several instruments were bought in London, and supervised and chosen by Magellan, the Portuguese instruments expert. We present arguments in favour of this conclusion.

Keywords: theodolite; Brazilian demarcations (>1778); J.H. de Magellan (1722-1790); history of scientific collections; eighteenth century history of science.

\section{Resumo}

Um antigo compasso topográfico em exibição no Museu de Astronomia e Ciências Afins (Mast), no Rio de Janeiro, chamou-nos a atenção por sua semelhança com um teodolito descrito por João Jacinto de Magalhães. Pouco era conhecido sobre sua história prévia. De acordo com os diversos documentos estudados e as caracteríticas desse único teodolito, ele deve ter pertencido às coleções de instrumentos adquiridos para a demarcação das fronteiras brasileiras realizadas após o Tratato de Santo Ildefonso, acordado entre as cortes portuguesa e espanhola em 1777. Vários instrumentos foram comprados em Londres, supervisionados e escolhidos por Magalhães, o perito português em instrumentos.

Apresentamos argumentos que corroboram essa conclusão.

Palavras-chave: teodolito; demarcações brasileiras (>1778); João Jacinto de Magalhães (1722-1790); história de coleções científicas; século XVIII/história da ciência. 
Tn October of 1777, the Courts of Portugal and Spain signed the important Santo Ildefonso 1 Treaty, where they agreed on new operations for readjusting the Brazilian frontiers, following and going further than the Treaty of Madrid (1750).

A fast development of precision instruments - both in their conception and also in their production, materials, and accuracy - took place during the last quarter of the century. A project like the Brazilian demarcations needed updated instruments, and that was in the rulers' and practitioners' minds. The Portuguese instrument expert settled in London, João Jacinto de Magalhães (better known as J.H. de Magellan, 1722-1790), was commissioned to choose and supervise the acquisition of the astronomical and physics instruments required for performing those operations. The Spanish Court also agreed that Magellan should be their representative to superintend the Spanish equipment. The two courts conveyed that their collections should be complimentary. In a short time, 11 collections of instruments were produced and crossed the Atlantic for that program (Malaquias, 2014a).

How does this fit with the topographic compass/theodolite we are dealing with?

\section{The instrument at present}

The description of this instrument at the Museum of Astronomy and Related Sciences (Museu de Astronomia e Ciências Afins, MAST) labels it as a topographic compass made by "G. Adams, London," following the engraving present near the compass border. It has the Registration Number: 1994/0221 a, b, c (MAST, 2011).

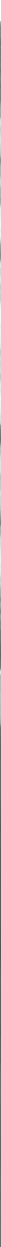


In the oldest card, produced in 1984, it is said that it comes from the nineteenth century, and that it was made in England. ${ }^{1}$ Nothing else is registered concerning the theodolite's travelling route or acquisition. Regarding the instrument characteristics, some dimensions are offered, namely the height of $29.5 \mathrm{~cm}$, a depth of $31 \mathrm{~cm}$, and the $17 \mathrm{~cm}$ compass diameter. The vertical circle is $23 \mathrm{~cm}$, and the horizontal circle is $25 \mathrm{~cm}$.

A more recent card (1994) presents some slight differences concerning the dimensions taken, and classifies the instrument as belonging to the class of the precision instruments /Optics. As previously identified, its functions correspond to surveying for guidance and measurement of angles indicating the magnetic meridian direction of a given point. However, it advances some new information relative to the room where the instrument is preserved, ${ }^{2}$ and reveals in the acquisition item that it came from the "warehouse." It presents the date March 8, 1985, and that it proceeds from the National Observatory (implicitly in Rio de Janeiro). It is also written that this information was provided by a former employee of the National Observatory.

Comparing these two cards, some differences are present in the item "acquisition dates" that most probably refer to the instrument's entrance at MAST, apart from the difference of one day and one year that must be a copy mistake. The second information on its provenance is interesting and plausible, in the sense that it is explicitly mentioned that it came from a former staff member and unveils a little bit of what we are trying to find out.

Our information taken upon observation (Figure 1) gives $24.5 \mathrm{~cm}$ to the larger diameter and $14.9 \mathrm{~cm}$ to the length of the magnetic needle. The telescope has a $29.5 \mathrm{~cm}$ length. There are some missing parts of the instrument, namely the telescope lens. The horizontal circular base is graduated and possesses a nonium (vernier) (Figure 2). There exist two perpendicular vertical arcs of circles upon the magnetic compass, fixed in opposite directions. One of them is a racked arc of a circle over which the telescope can move. It is graduated from $30^{\circ}-0^{\circ}-30^{\circ}$ and presents a superimposed nonium (Figures 3,4 , and 5). ${ }^{3}$

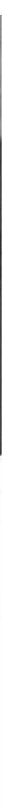




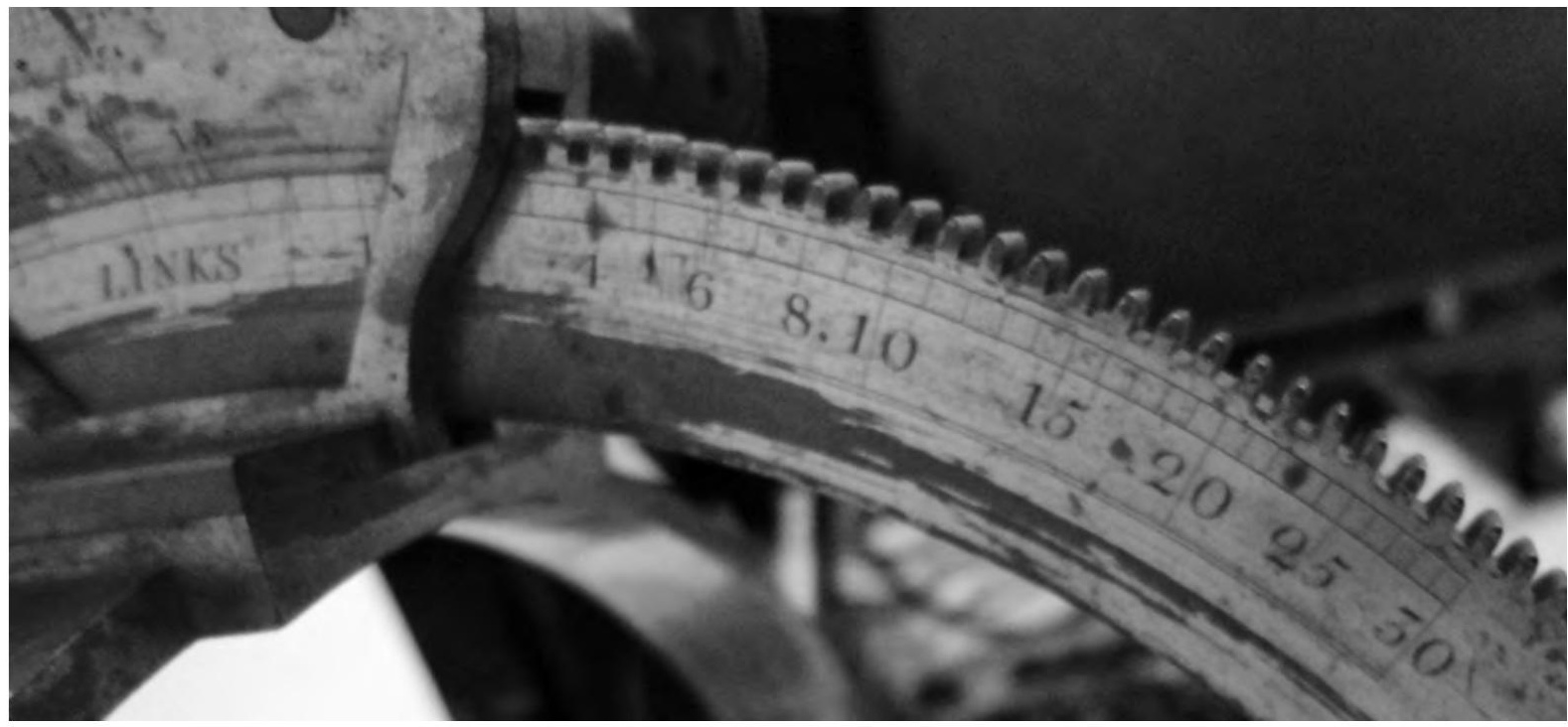

Figure 3: Detail of the vertical rack graduation (Photo by I. Malaquias)

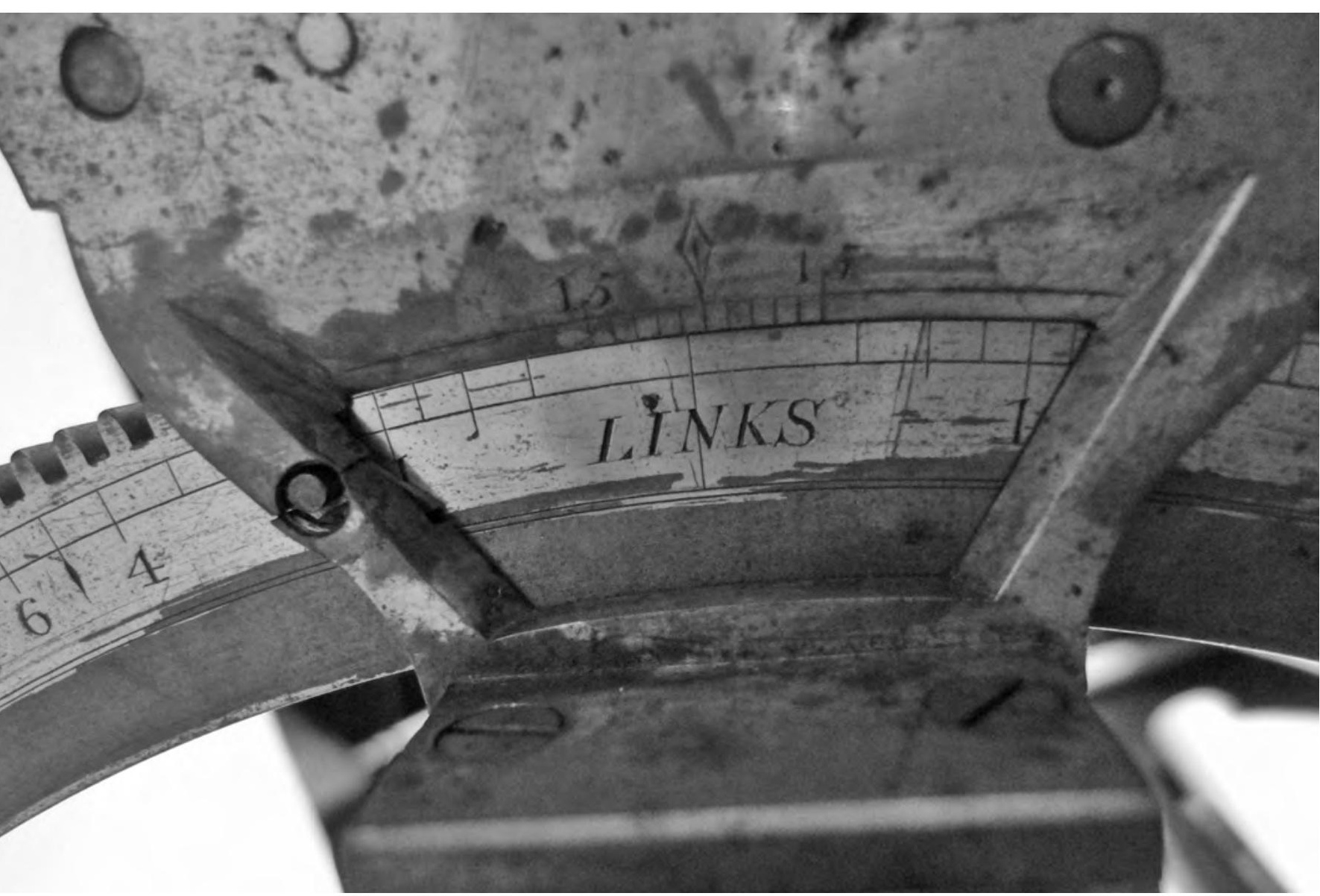

Figure 4: Detail of the nonium (Photo by I. Malaquias) 


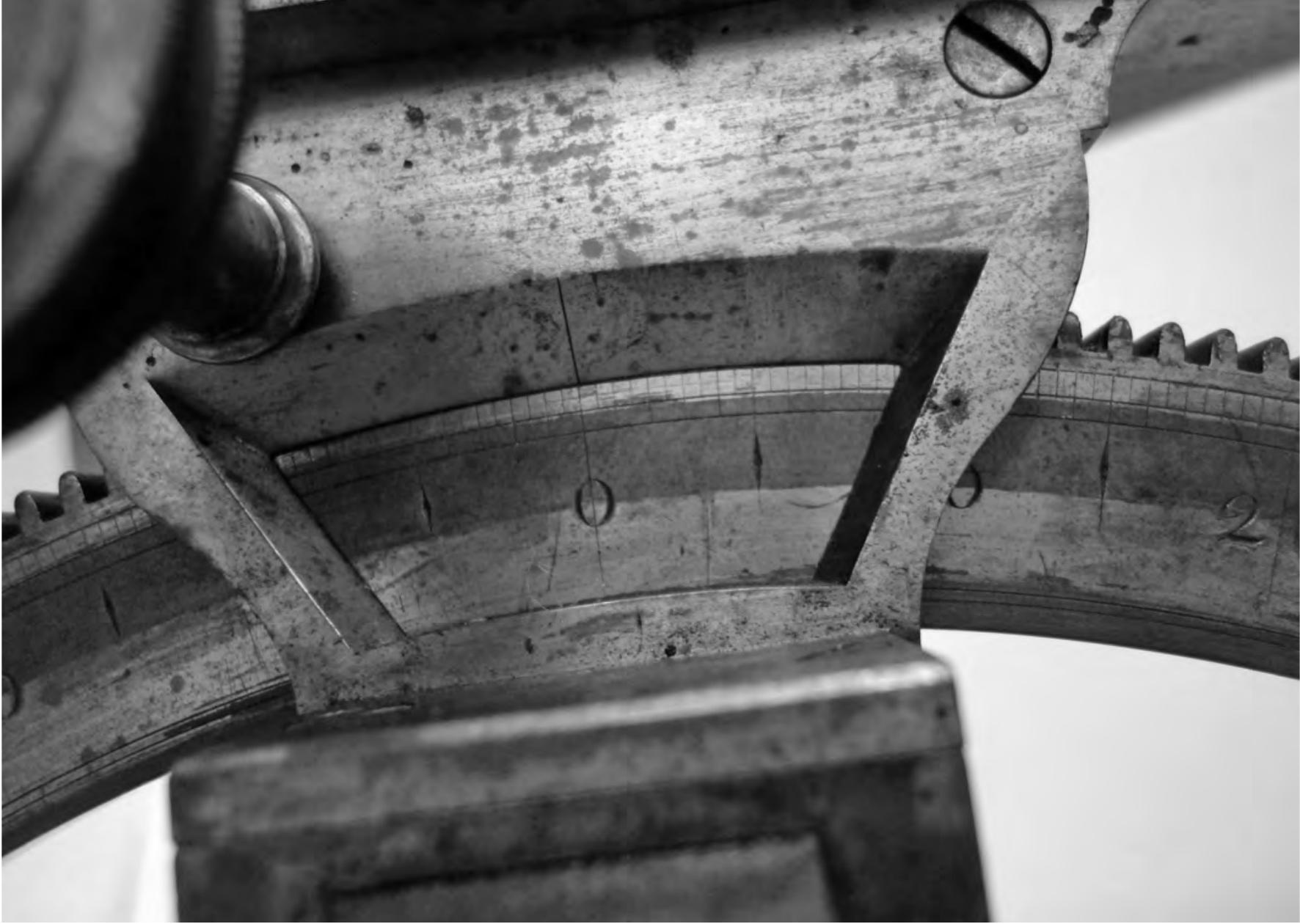

Figure 5: Detail of the vertical nonium opposite side (Photo by I. Malaquias)

\section{More on the probable travelling path}

Several documents concerning the instrument's acquisition for the Brazilian demarcations of the second half of the eighteenth century still remain in the Portuguese archives. From some of them we get a more direct reference to theodolites that were ordered at the time. More precisely, we find that on July 14, 1778, Magellan was informing the Portuguese ambassador $^{4}$ in London on the progress of the requests relative to the instruments for the Portuguese astronomers/surveyors. He relayed to the ambassador that it was then a bit late to modify the way the compasses were being constructed. More precisely, he considers that:

The needles to determine the magnetic variation, are already very advanced, to give another form to its construction, but if it were not so, the circumstance of having a vertical circle with their divisions to determine the azimuth angles, can certainly be very advantageous in several occasions which lack an astronomic quadrant. Besides that, the Order received from the Spanish Court for instruments being similar to this List of Portugal, points expressly to 6 Theodolites: and I imagine that the Portuguese astronomers will not be unhappy to own instruments with the same properties to which I will join, if Your Excellency approves, many other surveyor chains, as in the said Spanish order is determined (Magalhaens, 14 July 1778; emphasis added).

The collections for the Portuguese court were completed and sent on July 2, 1779 following Magellan's mention that he has received the necessary money to pay the different instrument 
makers for all the instruments in the Portuguese collections (Malaquias, 2014a). From the list of instruments acquired, one reads " 5 azimuthal needles by Adams ... 10 pocket magnetic needles each with a support in the shape of a walking stick" (Magalhães, 2 July 1779). From what is said, the compasses here referred to were not yet of an altazimuth variety, but most certainly just compasses with vertical sights (Figure 6: Fig.72), although Magellan would envisage the possibility of adapting a vertical graduated circle as mentioned above.

At that date, the collections ordered by the Spanish minister in England, Chevalier Escarano, had been in preparation since the previous year, and took a few months more to be completed and dispatched. Magellan intended to write and publish several booklets with descriptions and instructions for use of every instrument in the different collections. However, health problems limited his intentions and he prepared just a few booklets to be used either by the Portuguese or the Spanish astronomers, avoiding duplicated efforts. They were sent free of charge to the Iberian courts, as Magellan was proud to serve them both, following his ancestor's way (the Portuguese Fernão de Magalhães, the circumnavigator) (Malaquias, 2008, 2014a, 2014b).

\section{Magellan's description}

In the collection's descriptions for Spain (1780), Magellan refers to the theodolite ordered and presents a drawing illustrating one of those included. In particular, the contents of Box 9 belonging to Collection No.1 refer to one theodolite to be used with a tripod. Magellan (1780) details some parts of the theodolite in the text and in the corresponding drawings (Figure 6). George Adams was the instrument maker that produced it with great care, testifies Magellan, mentioning that he gave priority to the construction of this instrument "whose invention is attributed to the late Mr. Harris, Director of the London Mint." ${ }^{5}$ And Magellan continues, considering that

This construction has all the benefits you could want with this instrument; and in the same time, it admits in its centre a needle of sufficient magnitude to be useful for what I proposed to observe, with this instrument, the magnetic variation much more accurately than by any other method known. This is what I had already done with the instruments for the Court of Portugal and I had the satisfaction to see and learn that my ideas had obtained all the success imaginable, and the Scientists' approval (Magellan, 1780, p.226). ${ }^{6}$

We know that the collections for both courts were similar, although a theodolite description is not included in the published booklets addressed to the Portuguese court. However, from the excerpt initially mentioned above (1778) concerning the communication with the Portuguese ambassador in London, and from this last passage, we get knowledge that in the time gap between the two communications mentioned they had also been produced and tested for the Portuguese collections.

Magellan points out that the theodolite includes two opposite nonius (marked $a$ and $b$ in Figure 6) to control any variation in the observation caused by defects on the horizontal divided circle (with "about ten and a half British inches"). The occurrence of a variation would be easily perceived, since every minute is "no more than one thousandth and a half 
(0.0015) of a British inch; it is the amount that the two Nonius would not fail to show, if it

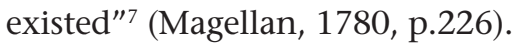

It possesses two telescopes ( $f g$ and $d e$ ); the second one ( $d e$ ) can be fixed with a screw, below the horizontal circle $a c b$, and can be moved either in the horizontal or vertical plans, so that an object can be observed at the centre of its crossed wires field. This enables the user to ensure that the instrument did not move from its first position and that observations with the other telescope $(f g)$ can then be made.

In what follows, Magellan (1780, p.227) continues detailing the method to accurately observe the magnetic declination, "which is the subject of the particular construction of my invention, I did adapt successfully to that of these Theodolites. Here is how it must be taken, to observe with the greatest accuracy" (emphasis added). ${ }^{8}$

For that, it is necessary at first to proceed with all the adjustments needed for geodesy, so that the horizontal circle $a c b$ is parallel to the horizon and the vertical nonius of the first telescope $(f g)$ be fixed at zero in the vertical arc of the circle. At the same time, the air bubble level $(k k)$, near this telescope, must be positioned in its middle. The true meridian line must be found after the horizontal plan circle is adjusted and the collimation line be secured within the telescope $(f g)$. It is then possible to point out to a terrestrial object with the other telescope (de). The true direction of the meridian line can be found afterwards, either by having fixed
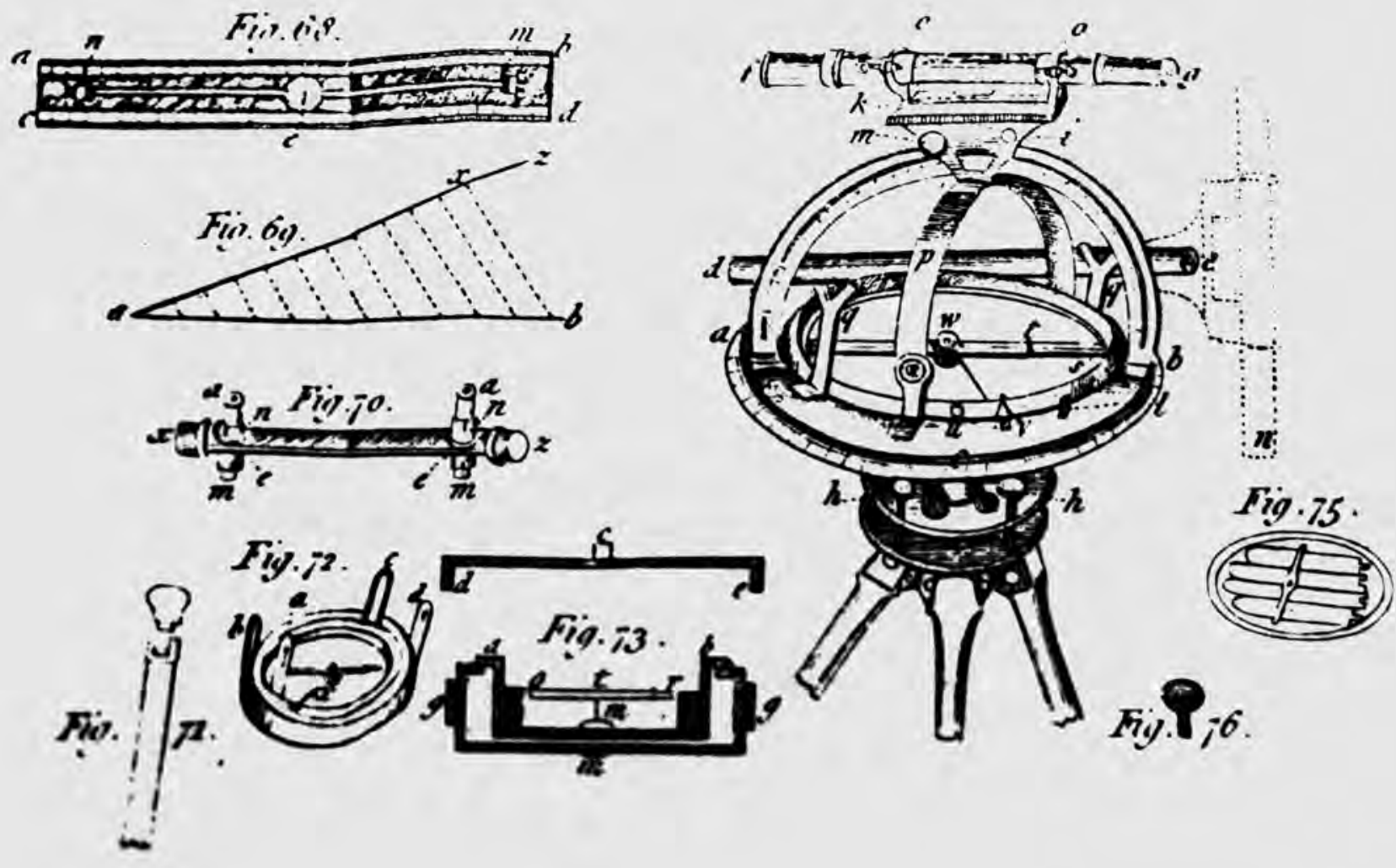

Figure 6: Drawing of the theodolite (Magellan, 1780; photo by I. Malaquias) 
some object or mark, or by knowing the hour angle using a clock, and find it by taking the sun line with the telescope $(f g)$ to obtain the azimuthal angle (using a dark glass).

After having secured the theodolite degree and minute on which the meridian line passes, it is possible to free the telescope $f g$ from its location and mount it on the two forks marked qq. Then one can adjust the instrument, by rotation of the screw, $l$, to which adapts the knob marked as Fig.76, until the meridian line is observed again in the centre of the telescope. This enables getting the angular measure the forks' direction has towards the meridian line. Removing the telescope $f g$ from the forks, it is necessary to put them on the tube, $x z$, that contains two microscopes - am, am (Figure 6 - Fig.70) with crossed wires on each. Rotating the screw, $l$, again it is possible to adjust the two wires in each microscope with the needle's central direction while they coincide with the $45^{\circ} \& 225^{\circ}$ direction of the compass interior circle, while the other right angle wires will be parallel to the tangent of the compass' circle. In this regard, Magellan (1780, p.237) makes some considerations on the graduation of the compass and on what is observed (in an inverted position) through the microscopes, also referring to the differences one can find when observing with a terrestrial compass and with a sea compass. Moreover he mentions the necessity of carefully repeating the measurements, namely turning up the magnetic needle, and adjusting this one with the slight small ring it presents to better equilibrate it on its pivot.

A detail of the compass divisions is presented in Figure 7.

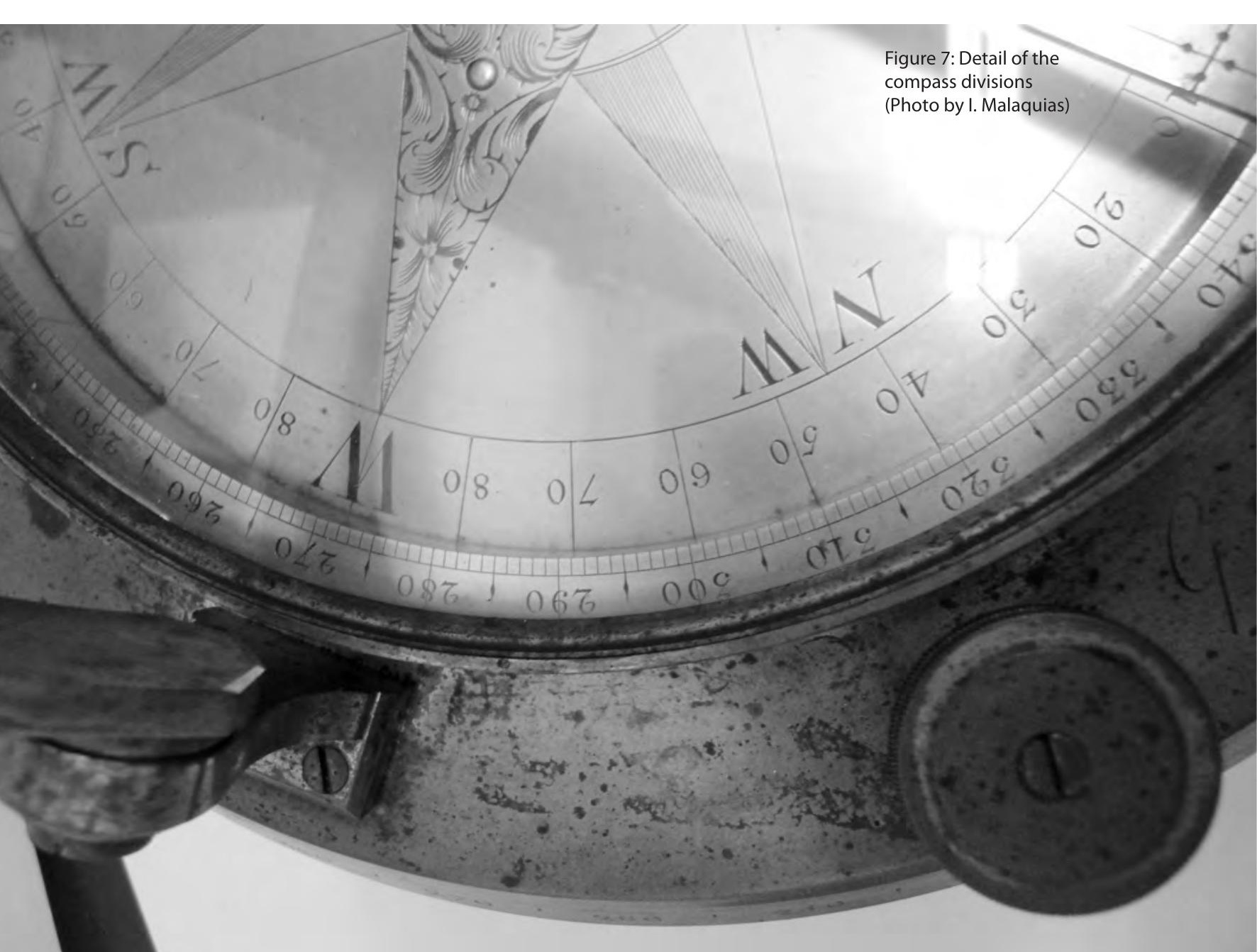




\section{George Adams Junior's advertisements}

In his Geometrical and graphical essays, published in 1791, George Adams Jr. presents drawings of theodolites, one of them improved by Ramsden (Figure 9). At that date, Magellan had already passed away, but confronting those instruments with the present theodolite, some differences are revealed that mainly correspond to the vertical ring and the compass placement in relation to the spyglass and the telescope (in the second theodolite). Ramsden's instrument seems more robust than Adams's version made for Magellan, and both are a lot more robust than some other simpler theodolites produced at Adams' workshop. In particular, we can realise that by looking at the Adams' theodolite dated circa 1790 displayed online at Astonishing Science Spectacular Museum. ${ }^{9}$

Following another Adams' advertisement, published in A Catalogue of Mathematical and Philosophical instruments (1795), information on some theodolites is found. No pictures are provided. In particular:

A small theodolet [sic], with telescopic sights and vertical arch, from 10l. 10s. to - $£$ 21. 0. 0

Larger ditto with the vertical arch affixed to a long axis - $£ 14.14 .0$

A larger ditto, like the preceding, only moving with rack-work - $£ 21.0 .0$

The latest improved theodolite, with double telescope, and every requisite adjustment - £36.16.0 (Appendix II, “A catalogue...”, found in Millburn, 2000, p.372)

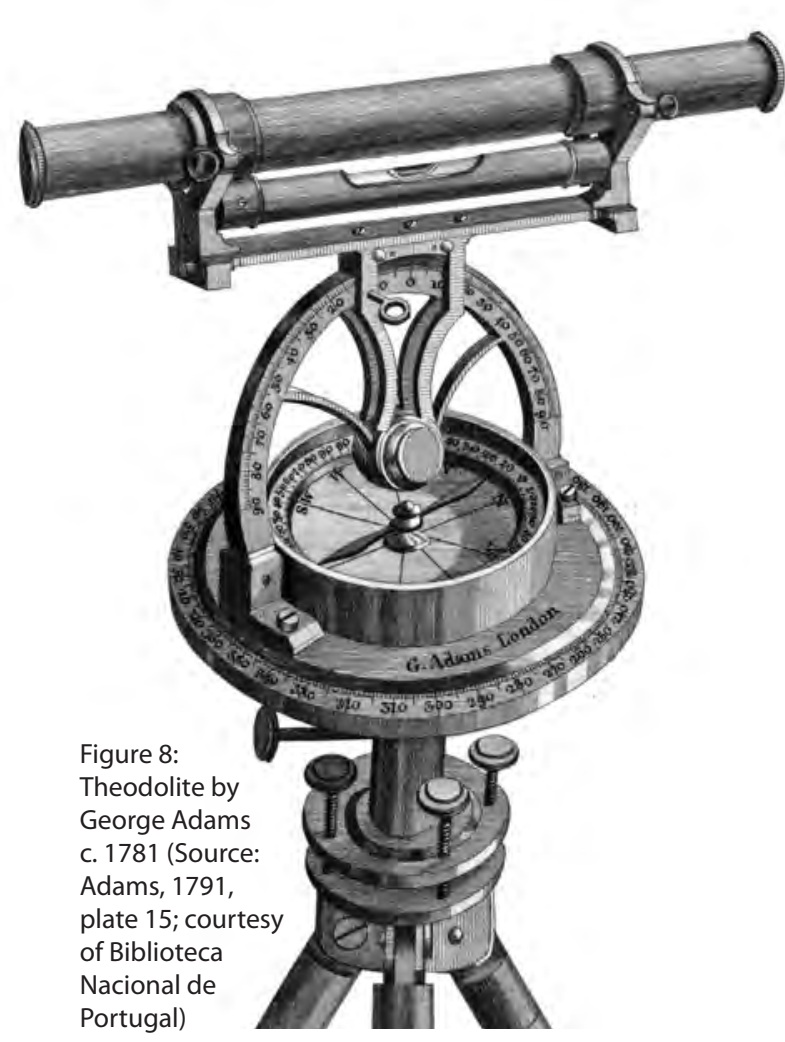

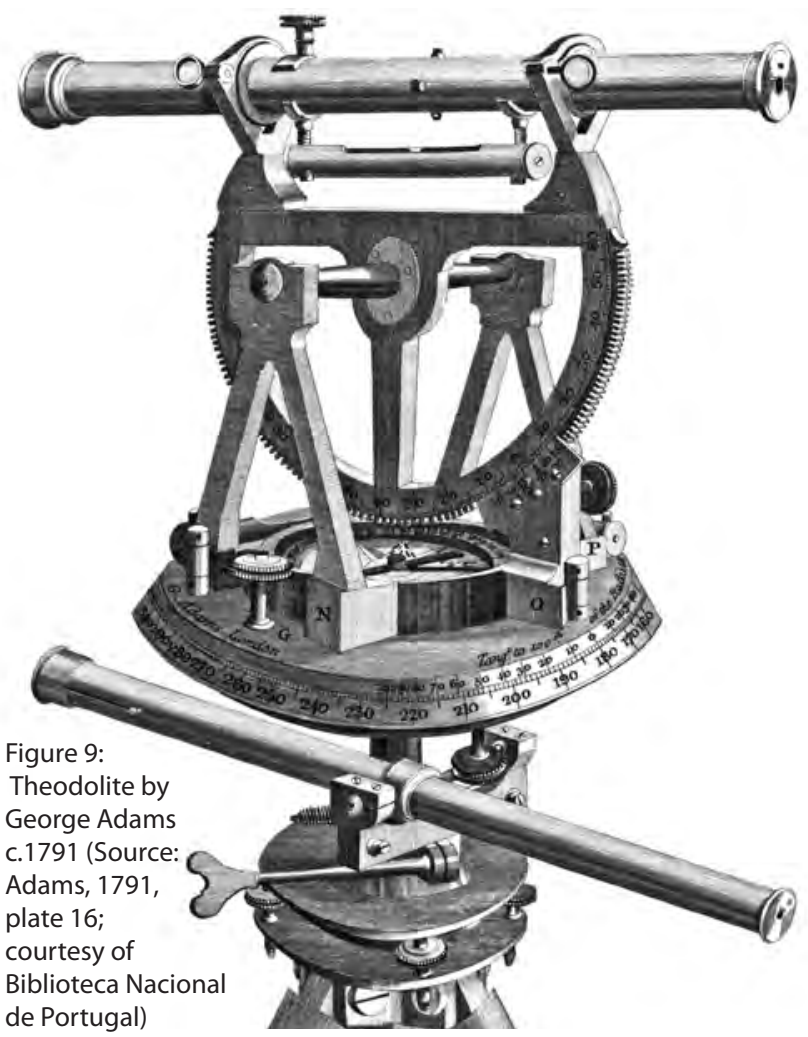




\section{Other evidence}

The Brazilian frontier demarcations were a huge enterprise that was implemented during several years. The acquisition of instruments also continued after the initial eleven collections production (five to Portugal and six to Spain), although not in such a large amount. Drawing on archival sources, some other findings were released. From the Portuguese side, there still remains a documented order for a theodolite required for the works being developed in Rio Negro, Brazil. In fact, the Portuguese ambassador in London writing to the Minister Martinho de Melo e Castro in Lisbon mentions that following the orders received on June 10, 1786, to acquire a theodolite for the referred demarcation, he was able to declare that the instrument was already sent on the ship St. Jorge, whose captain was Jaime Williamson. The instrument would be inside a box numbered as "N.13" and marked with a capital M above which was a crown symbol (meaning 'Majesty', most probably) (Sousa, 10 June 1786, doc. n.741). From the same document, we learn that Magellan charged $£ 36$ : 15 for the theodolite. We do not have more particular details on this theodolite, but the price advertised in 1795 by Adams Junior for "The latest improved theodolite, with double telescope, and every requisite adjustment [was] £36.16.0" (Millburn, 2000, p.373).

Was this the type of theodolite we have been dealing with?

The first collections ordered by the Spanish Court contained already six theodolites as Magellan informed the Portuguese Court about them, asking permission to add similar instruments to the Portuguese collections.

The Spanish collections of instruments were ready a few months later after the Portuguese. In what refers to the theodolite, its description was inserted in their collections. So we can consider that in 1780, theodolites were already being tested to sail out to Brazil and to the Spanish "commissions"10 that were delayed until 1783. In later correspondence with the Spanish ambassador, Magellan gives an account of "Two compasses or variation needles, united with two Theodolites (Adams' bill) ... 35 guineas ... [£] 73: 10: 0."11

In the present day, the surviving Spanish collections also refer to a theodolite that does not exist anymore according to Dr. Francisco Gonzalez, curator in San Fernando Observatory, in Cadiz. If it remained, it would be interesting to compare it with this one that belongs now to MAST, as happened in the case of the Jeremiah Sisson's quadrants (Malaquias, 2014a).

\section{Final considerations}

From the documents analysed, we believe that the George Adams' theodolite in Rio de Janeiro must have belonged to the collections of instruments that were sent for the Brazilian demarcations after the Santo Ildefonso Treaty (1777) between Portugal and Spain. J.H. de Magellan was in charge of the acquisition of the whole commission for British instruments. In the collections made for Spain, produced a bit later than those for Portugal, there is an explicit register and description of theodolites together with an illustrative drawing. Matching the present instrument with the drawing, there exists an affinity between both that drove our attention since the beginning. However, some differences and/or missing pieces are present. The existent theodolite does not seem to have a fixing part for the second telescope, although 
it shows the two forks. For this second telescope, the tube with microscopes and the air bubble level seem to have disappeared, as well as the box to keep the theodolite together with some small dark glasses, screws, the tripod with leveling screws etc. that were reported to exist.

In Spain it seems there are no more extant theodolites from those scientific missions. In the Portuguese case, the one in MAST seems to be the last remaining. Other archival documentation related to Brazil specifies a theodolite ordered for the demarcations held at Rio Negro (1786), leading us to conceive that after those works the commission in charge must have brought the instrument to the capital of Rio de Janeiro, if it was not one of the others that went previously to other places in the frontier.

Different institutional modifications, occurring during the mid-nineteenth and twentieth centuries, must have led to the present instrument in evidence at MAST. Our hypothesis stands on the condition that an expensive precision instrument would not be left behind in the interior part of Brazil after the demarcation works unless it was damaged forever. If that were not the case, it should have returned to Rio de Janeiro. Moreover it would not have been impossible that it even had returned to Portugal, where in 1788 the program for the kingdom's triangulation begun, following the Paris-Greenwich enterprise. That was the aftermath of some of the Spanish instruments. However, by the end of the century Portuguese State politics were favourable to moving the capital to Brazil in order to better lead the large Portuguese empire. The French invasions at the beginning of the following century forced the move of the Queen and the royal family to Rio de Janeiro. Finally, it does not seem that a similar theodolite is found at present in the Portuguese collections where remains of the triangulation program still exist.

After such a long voyage, since it was produced in London at the George Adams Junior's workshop, this exemplar looks like a rare copy of an Adams theodolite, to which Magellan could add some few modifications that may turn this instrument into a singular model among other theodolites of the period. A probable date range of 1779 to 1787 is conceivable for this theodolite presently belonging to the Museu de Astronomia e Ciências Afins in Rio de Janeiro, Brazil, as a memory of those times.

\section{ACKNOWLEDGMENTS}

The author deeply thanks Maria Margaret Lopes, then Director of Museu de Astronomia e Ciências Afins (MAST) for all the support and facilities given, and to Katia Bello for all her help.

\section{NOTES}

${ }^{1}$ More precisely, it is dated March 9, 1984 and contains the following information:

Dimensions| height: 29,5 cm | width: $25 \mathrm{~cm}$ |length: _ |depth: $31 \mathrm{~cm}$ |

Diameter: compass $17 \mathrm{~cm}$ | Weight:

Lunettes or telescopes / Opening - Focal Dist.__ Circles / Diameters

$\mathrm{O}=2,5 \mathrm{~cm} \quad$ C. V. = --------------- $\mid$ C. V. $=23 \mathrm{~cm}$

$\mathrm{df}=31 \mathrm{~cm} \quad$ C. H. $=---------------\mid$ C. $\mathrm{H} .=25 \mathrm{~cm}$

Conservation status: Poor (Good, Fair, Poor, Terrible)

Date in Institution:

Notes: Instrument found incomplete. 
Missing the lens of the telescope and bubble level

Description / History:

Graduation from the right to the left

Compass with a circular basis graduated from 0 to 360 in whose center is fixed below a device for adjusting a tripod.

Upon this, another one movable, containing the holders' level; the arc of a circle with a vertical rack; the ring perpendicular to the arc, which fixes the movable bezel around the arc, and the telescope small displacement screw. The compass protected with glass displaying the cardinal and collateral points being the vertical arc oriented towards the cardinal N. Those points are reversed. An annular shoulder is graded from 0 to 360, where 0 corresponds with the $\mathrm{N}$ rose. It possesses a magnetic needle, a needle fixing screw and a small displacement screw for the graded base.

${ }^{2}$ mob 8 B3 - room 11.

${ }^{3}$ The reason why the graduation runs from $30^{\circ}-0^{\circ}-30^{\circ}$ must be concerned with the fact that the measured vertical angles are intended to be introduced in mathematical formulas, and tables, to be reduced to the horizon. Calculating an angle by its tangent (or sinus), the worse situation arrives when the angle comes to be $45^{\circ}$. The error grows with the growing angle (see D'Almeida, Guimarães, 1899).

${ }^{4}$ This letter was annexed to Luís Pinto de Sousa letter to the Foreign Office Minister Ayres de Sá e Mello, dated the same day, mentioned in Pinto de Sousa's Oporto Copybook and whose original resides at the Arquivos Nacionais da Torre do Tombo in Lisbon.

${ }^{5}$ Joseph Harris (1702-1764) conceived an improved azimuth compass (Taylor, 1966).

6 "Cette construction a tous les avantages qu'on peut souhaiter dans cet instrument; \& dans le meme temps, elle admet, dans son centre, une aiguille aimantée de la grandeur suffisante, pour l'objet que je me suis proposé de pouvoir observer, avec cet instrument, la variation magnétique beaucoup plus exactement, que par aucune autre méthode connue. C'est ce que j'avois fait déjà dans les instruments pour la Cour de Portugal: \& j'eus la satisfaction de voir \& d'apprendre, que mes idées avoient obtenû tout le succès imaginable, \& l'approbation des Savants."

7 "puisque chaque minute n'est qu'un millième \& demi $(0,0015)$ d'un pouce d'Angleterre; \& celle-ci est la quantité que les deux Nonius ne manqueroient pas de montrer, si elle y existoit."

8 " qui est l'objet de la construction particulière de mon invention, que j'ai fait adapter, avec succès, à celle de ces Théodolites. Voici, comm'il faut s'y prendre, pour l'observer avec la plus grande exactitude."

${ }_{9}$ Available at: http://landsurveyorsunited.com/photo/circa-1790-george-adams-theodolite. Access: 1 May 2013.

${ }^{10}$ What we are calling "commission" refers to the Portuguese designation of the Brazilian partidas that were composed of around half a dozen men that went in groups to perform the surveys and set the boundaries in the lands.

11 "Deux compass ou Aguias de variation unies à deux Theodolites (bill d'Adams) ... à 35 guinées ..... [£] 73: 10: 0." Magellan to Don Bernardo del Campo, dated February 8, 1785. All the surviving correspondence to or from Magellan is about to be published by the author, together with Roderick Home and Manuel F. Thomaz.

\section{REFERENCES}

ADAMS, George.

Geometrical and graphical essays, containing a description of the mathematical instruments used in geometry, civil and military surveying, leveling and perspective with many new problems illustrative of each branch. London. 1791.

D'ALMEIDA, A. Mendes; GUIMARÃES, Rodolpho.

Curso de topographia. v.1. Lisboa: Livraria Rodrigues. 1899.
MAGELLAN, J.H. de.

Notice des Instrumens d'Astronomie, de Geodesie, et de Physique, \&c. Faits à Londres pour la Cour d'Espagne, \&c. Londres, Imprimerie de W. Richardson. p.225. 1780.

MAGALHÃES, João Hyacintho de.

Carta a Luís Pinto de Sousa. Copiador de correspondência; Ms.313, No.328 annex -1779.07.02 (Biblioteca Pública Municipal do Porto, Porto). 2 July 1779. 
MAGALHAENS, João Hyacintho de. Carta a Luís Pinto de Sousa. Arquivo Histórico Ultramarino, Conselho Ultramarino-Reino; CX 258, antigo Maço 2015, 1778.07.14 (Arquivo Histórico Ultramarino, Lisboa). 14 July 1778.

MALAQUIAS, Isabel.

Instruments in transit: the Santo Ildefonso Treaty and the Brazilian border demarcations. In: Granato, Marcus; Lourenço, Marta C. (Ed.). Scientific instruments in the history of science: studies in transfer, use and preservation. Rio de Janeiro: MAST. p. 101-115. 2014. Available at: http://www.mast.br/scientific_instruments_in_ the_history_of_science_studies_in_transfer_use and_preservation/MALAQUIAS_p101-115.pdf. Access on: 29 April 2016. 2014a.

MALAQUIAS, Isabel.

Between astronomy and instrumentation: João Jacinto de Magalhães (1722-1790), a remarkable case. In: Saraiva, L. (Ed.). Proceedings of the International Conference - History of Astronomy in Portugal: institutions, theories, practices. Porto: Sociedade Portuguesa de Astronomia. p.265-277. 2014b.
MALAQUIAS, Isabel.

Aspects of the scientific network and communication of John Hyacinth de Magellan in Britain, Flanders and France. Ambix, v.55, n.3, p.255-273. 2008.

MAST.

Museu de Astronomia e Ciências Afins. Inventário da coleção de objetos de ciência e tecnologia do Museu de Astronomia e Ciências Afins. Rio de Janeiro: MAST. p.112. 2011.

MILLBURN, John R.

Adams of Fleet Street instrument makers to King George III. Aldershot: Ashgate. 2000.

SOUSA, Luís Pinto de.

Carta a Martinho de Melo e Castro. Copiador de correspondência; doc. n.741-1786.06.10 (Biblioteca Pública Municipal do Porto, Porto). 10 June 1786.

TAYLOR, E.G.R.

The mathematical practitioners of Hanoverian England, 1714-1840. Cambridge: For the Institute of Navigation at the University Press. 1966.

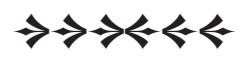

